\title{
PERANCANGAN SISTEM INFORMASI PELATIHAN KOPERASI UJI MUTU BERBASIS WEB
}

\author{
Darmawan Baginda Napitupulu \\ Pusat Penelitian Sistem Mutu dan Teknologi Pengujian, Lembaga Ilmu Pengetahuan Indonesia, \\ Tangerang, Indonesia \\ darwan_napit@yahoo.com
}

\begin{abstract}
Abstrak
Telah dirancang sistem informasi pelatihan Koperasi Uji Mutu (KUM) berbasis web yang diterapkan pada koperasi Pusat Penelitian Sistem Mutu dan Teknologi Pengujian. Perancangan sistem informasi pelatihan Koperasi Uji Mutu (KUM) menggunakan metode diagram konteks dan diagram use case untuk mengidentifikasi entitas, data dan proses-proses apa saja yang terjadi di dalam sistem. Hasil dari tulisan ini adalah berupa prototipe sistem informasi pelatihan Koperasi Uji Mutu (KUM) berbasis web yang dapat diakses oleh pengunjung ataupun pengguna jasa pelatihan dan meliputi semua fungsi yang telah diidentifikasi sebelumnya.
\end{abstract}

Kata kunci: Koperasi, Pelatihan, Sistem Informasi , Uji Mutu, use case, web

\section{Pendahuluan}

Keberadaan koperasi di tengah krisis ekonomi yang melanda negeri ini sangatlah dibutuhkan, terutama untuk menunjang usaha-usaha kecil dan menengah (UKM). Agar suatu koperasi bisa berkembang, koperasi memerlukan penghasilan baik melalui simpanan pokok dan simpanan wajib yang merupakan tabungan anggotanya secara rutin maupun melalui kegiatan-kegiatan usaha yang dilakukan koperasi itu sendiri. Seperti simpan pinjam, toko yang menjual barang-barang konsumsi, dan lain-lain.

Koperasi sebenarnya tidak hanya sebagai wadah bagi usaha kecil dan menengah (UKM), namun bila koperasi-koperasi tersebut bergabung maka dapat menjadi wadah bagi usaha-usaha skala besar. Sebagai contoh GKBI (Gabungan Koperasi Batik Indonesia) yang merupakan gabungan koperasikoperasi batik di Indonesia. Dengan modal yang dikumpulkan dari seluruh anggotanya, GKBI telah berhasil membangun sebuah industri tekstil di Indonesia [1].

Dengan demikian, koperasi dapat menjadi tulang punggung perekonomian yang dapat menggerakkan roda perekonomian bangsa mulai dengan membantu usaha kecil dan menengah (UKM) dalam hal permodalan hingga usaha besar.

Secara definisi, koperasi adalah kumpulan orang-orang atau badan hukum yang bertujuan untuk perbaikan sosial ekonomi anggotanya dengan memenuhi kebutuhan ekonomi anggotanya, dengan jalan berusaha bersama saling membantu antara satu dengan lainnya dengan cara membatasi keuntungan. Usaha tersebut harus didasarkan prinsip-prinsip koperasi [2].

Sedangkan perkoperasian sendiri sudah diatur menurut Undang-Undang No 25 tahun 1992 yaitu tentang Perkoperasian Indonesia dimana koperasi didefinisikan sebagai badan usaha yang beranggotakan orang seorang atau badan hukum koperasi dengan melandaskan kegiatannya berdasarkan prinsip-prinsip koperasi sekaligus sebagai gerakan ekonomi rakyat yang berdasar atas asas kekeluargaan.

Dari definisi diatas, diharapkan koperasi bukan hanya menjadi slogan yang menawarkan konsep kebersamaan, kekeluargaan, gotong royong serta persamaan hak dan kewajiban saja melainkan koperasi mencoba untuk tumbuh dan berkembang untuk memenuhi kebutuhan masyarakat akan kemakmuran, kesejahteraan dan kehidupan yang layak secara adil. Hal ini yang sesuai dengan tujuan koperasi sebagaimana tertuang dalam UU No 25 Tahun 1992 yaitu memajukan kesejahteraan anggota pada khususnya dan masyarakat pada umumnya serta ikut membangun tatanan perekonomian nasional dalam rangka mewujudkan masyarakat yang maju, adil dan makmur berlandaskan Pancasila dan Undang-Undang Dasar 1945.

Demikian halnya dengan koperasi yang bernaung di bawah Lembaga Ilmu Pengetahuan Indonesia, tepatnya di Pusat Penelitian Sistem Mutu dan Teknologi Pengujian. Koperasi ini baru didirikan pada tahun 2006 dan dinamakan Koperasi 
Uji Mutu (KUM). Karena hanya beranggotakan sekitar 40 orang maka modal yang terkumpul dirasakan kurang memadai. Saat ini, koperasi memiliki dua jenis usaha yaitu toko dan kredit pinjaman. Toko yang dimiliki sangat sederhana, yaitu untuk menjual beberapa barang kebutuhan sehari-hari pegawai, sedangkan kredit pinjaman yang ditawarkan juga sangat kecil sehingga penghasilan yang diperoleh koperasi juga kecil. Padahal kalau dibandingkan dengan tujuan untuk mensejahterakan anggota, hal ini menjadi sangat sulit dilakukan.

Selain masalah modal, rendahnya kesadaran dan pengetahuan anggota tentang perkoperasian dimana pegawai masih membeli barang-barang kebutuhan sehari-hari dari luar koperasi. Hal ini tentu saja membuat barang-barang toko tidak laku terjual dan akhirnya menghambat perkembangan koperasi.

Untuk mengatasi masalah-masalah di atas, koperasi ingin menambah unit usaha baru yaitu jasa pelatihan. Produk pelatihan yang ditawarkan adalah pelatihan yang sesuai dengan kompetensi Pusat Penelitian Sistem Mutu dan Teknologi Pengujian yang didukung oleh ahli atau pakar di bidangnya sebagai pengajar. Hal ini dikarenakan koperasi berada di bawah Pusat Penelitian Sistem Mutu dan Teknologi Pengujian.

Produk pelatihan yang ditawarkan antara lain penerapan sistem manajemen mutu pada koperasi berbasis ISO 9001-2000, memahami ISO 14001 dan aplikasinya pada perusahaan, dan lain-lain. Untuk memasarkan produk-produk pelatihan tersebut, diperlukan sarana promosi. Salah satu sarana promosi yang efektif adalah melalui web karena dapat menjangkau daerah yang luas atau tidak terbatas secara geografis. Oleh karena itu, perlu dirancang sistem informasi pelatihan berbasis web yang bertujuan untuk menyebarluaskan informasi terutama mengenai produk pelatihan yang dimiliki.

Dalam makalah ini akan dibahas tentang perancangan sistem informasi berbasis web yang akan diterapkan pada koperasi uji mutu yang meliputi identifikasi kebutuhan atau fungsional dari sistem (entitas, data dan proses yang terjadi) hingga prototipe dari sistem informasi yang dirancang.

\section{Metodologi}

Metodologi yang digunakan dalam tulisan ini meliputi metode koleksi data dan metode perancangan sistem. Metode koleksi data meliputi studi pustaka tentang teknik-teknik pemograman berbasis web serta wawancara dengan pihak pengurus koperasi mengenai model dan fungsionalitas dari sistem. Sedangkan metode perancangan sistem terdiri diagram konteks dan diagram use case.

\section{Landasan Teori}

Dewasa ini Internet menjadi bahan perbincangan yang ramai dalam masyarakat baik tentang teknologinya maupun manfaatnya. Internet merupakan alat yang berpotensi untuk menjadi penyebar informasi yang cepat dan efektif.

Secara umum, Internet merupakan gabungan jaringan komputer yang berkomunikasi menggunakan prosedur atau aturan tertentu yang dikenal dengan protokol TCP/IP (Transmission Control Protocol/Internet Protocol).

Internet memberikan berbagai kemudahan yakni dapat mengakses informasi dari jarak jauh, IRC chat (berkomunikasi dengan individu lain di daerah atau belahan dunia lain), menghantar dan menerima e-mail, rangkaian newsgroup, memindahkan file antara satu komputer dengan komputer yang lain (ftp) dan akses ke WWW (World Wide Web).

Internet juga dapat membantu kelancaran kerja suatu organisasi bahkan menunjang kelangsungan hidup suatu organisasi atau perusahaan dimana organisasi atau perusahaan tersebut secara komersial perlu melakukan publikasi mengenai kegiatan-kegiatannya. Publikasi ini diperlukan agar masyarakat tertarik untuk ikut membantu, atau dalam konteks perusahaan komersial agar masyarakat tertarik untuk membeli produk usahanya itu.

$W e b$ adalah cara yang cukup efisien dan efektif untuk publikasi atau komersialisasi suatu produk dari perusahaan. Cara ini menjadi alternatif yang menguntungkan jika kita bandingkan dengan cara tradisional yaitu melalui media massa seperti koran, majalah, tv dan radio yang membutuhkan investasi besar.

Web merupakan sumber daya Internet yang sangat populer dan dapat digunakan untuk memperoleh informasi atau melakukan transaksi pembelian barang atau jasa. Web juga merupakan sistem pengiriman dokumen terbesar yang berjalan di Internet.

Seperti yang telah disebutkan pada bagian metodologi bahwa metode perancangan sistem yang digunakan adalah diagram konteks dan diagram use case. Diagram konteks merupakan suatu cara yang digunakan untuk menggambarkan entitas dan data yang terkait dengan sistem yang dirancang. Entitas adalah pihak-pihak yang akan berhubungan dan mengakses sistem. Data-data menunjukkan informasi apa saja yang dibutuhkan 
antara entitas dan sistem. Diagram konteks diperlukan untuk memperoleh gambaran dari sistem yang dirancang serta memudahkan untuk identifikasi fungsional atau proses-proses yang terjadi di dalam sistem.

Secara definisi, diagram use case adalah teknik dokumentasi kebutuhan-kebutuhan fungsional (requirements) dari sebuah sistem informasi. Kebutuhan fungsional tersebut merupakan prosesproses yang terjadi di dalam sistem. Diagram use case juga mendeskripsikan interaksi antara sistem dengan aktor eksternal untuk mencapai tujuan tertentu dimana setiap use case diinisiasi oleh

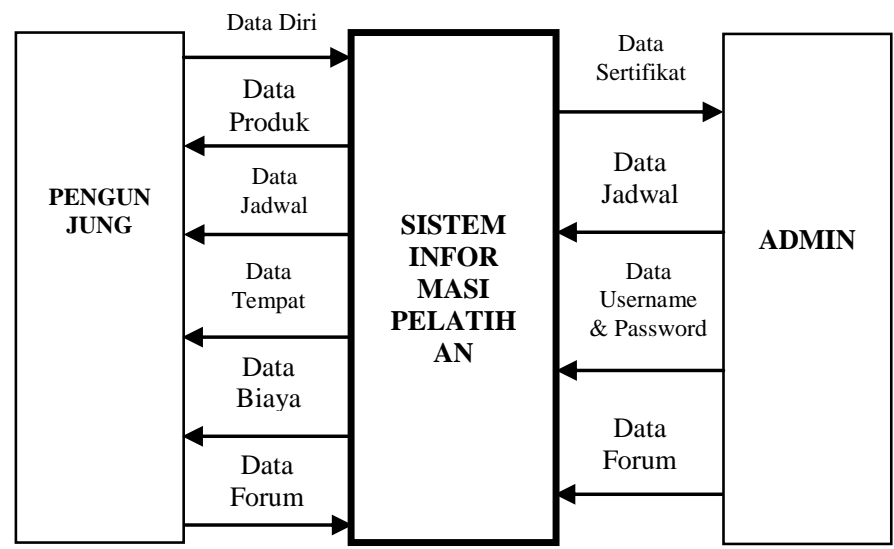

Gambar 1. Diagram Konteks Sistem Informasi Pelatihan Berbasis Web

aktor eksternal sistem yang disebut dengan pengguna. Dengan demikian diagram use case selalu dilihat dari sudut pandang pengguna.

\section{Perancangan Sistem}

Seperti yang disebutkan pada bagian pendahuluan bahwa sistem yang dirancang adalah berbasis web. Pilihan berbasis web (web based) ini diambil agar akses informasi atau transfer pengetahuan mengenai jasa pelatihan yang ditawarkan dapat dilakukan oleh siapa saja, kapan saja dan dimana saja [3].

Untuk menggambarkan entitas dan data-data yang terkait dengan sistem, digunakan diagram konteks seperti yang ditunjukkan pada Gambar 1 . Dari Gambar 1 terlihat bahwa entitas yang berhubungan dengan sistem adalah pengunjung dan administrator (admin).

Pengunjung adalah orang yang datang mengakses website sistem informasi pelatihan dan tertarik dengan jasa pelatihan yang ditawarkan. Sedangkan admin adalah orang yang bertugas mengelola website dengan melakukan updating beberapa isi dari web, mengatur jalannya forum diskusi hingga membuat sertifikat peserta yang lulus pelatihan.

Data-data yang terkait dengan sistem informasi pelatihan dilihat dari sudut pandang pengunjung adalah data diri, data produk, jadwal, tempat pelatihan, biaya dan data forum. Data diri dimasukkan pengguna bila ingin mendaftar sebagai peserta pelatihan tertentu. Data produk, jadwal, tempat pelatihan, biaya adalah data-data yang bisa diakses pengunjung dengan bebas. Data forum adalah data yang dimasukkan pengunjung bila ingin berdiskusi dalam forum mengenai topik pelatihan tertentu atau memberikan saran dan kritik terhadap kualitas website serta jasa pelatihan yang ditawarkan.

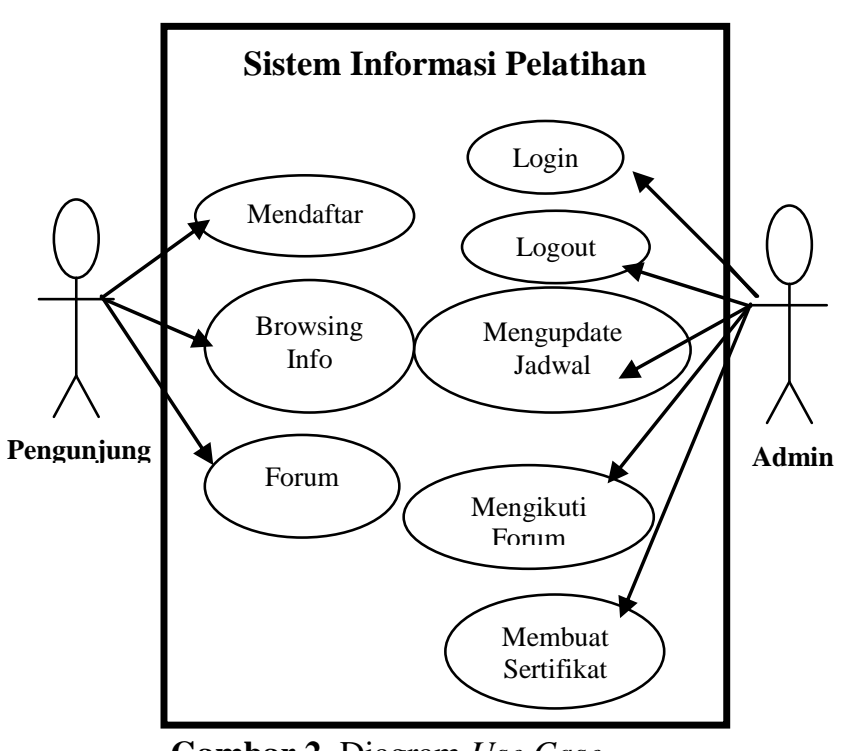

Gambar 2. Diagram Use Case

Sedangkan data-data yang terkait dengan sistem informasi pelatihan dilihat dari sudut pandang admin adalah data jadwal, username \& password, data forum dan data sertifikat. Data jadwal adalah data yang selalu diperbarui oleh admin mengenai jadwal dan jenis pelatihan tertentu yang akan diadakan. Data username \& password adalah data yang dimasukkan admin bila ingin memperbarui jadwal. Data forum adalah data yang diberikan untuk mengatur jalannya forum diskusi. Data sertifikat adalah bila admin akan membuat sertifikat bagi peserta pelatihan yang lulus.

Berdasarkan diagram konteks, kita bisa membuat diagram use case untuk menggambarkan kebutuhan fungsional atau dengan kata lain prosesproses yang terjadi di dalam sistem seperti yang ditunjukkan pada Gambar 2

Dari Gambar 2 terlihat bahwa fungsi-fungsi yang harus ada dalam sistem diidentifikasi dari 
kedua entitas yaitu pengunjung dan admin karena setiap use case diinisiasi dari entitas tersebut.

Fungsi-fungsi dari sudut pandang pengunjung adalah mendaftar, browsing info dan mengikuti forum. Proses mendaftar pelatihan dilakukan dengan mengisi formulir pendaftaran yang disediakan meliputi nama, instansi, jabatan, telepon, dan lain-lain. Kemudian data-data yang diisikan disimpan dalam sebuah database yaitu database pendaftaran. Proses browsing info adalah bilamana pengunjung ingin lebih mengetahui detail dari proses penyelenggaraan pelatihan seperti jenis pelatihan, jadwal pelatihan, tempat, biaya, berita, dan lain-lain. Proses mengikuti forum adalah proses dimana pengunjung berdiskusi tentang suatu topik pelatihan tertentu atau memberikan saran dan kritik.

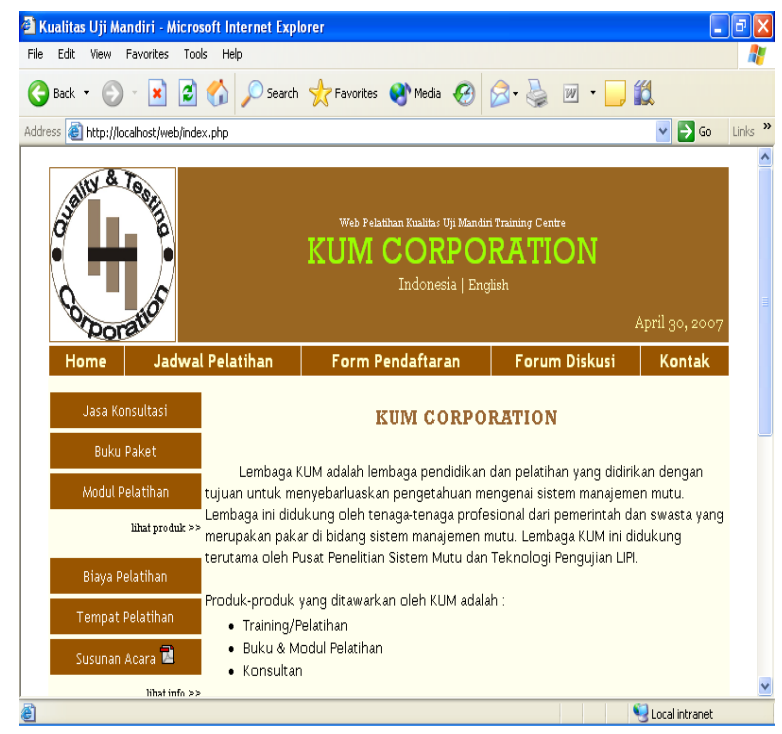

Gambar 3. Tampilan Muka (HomePage) Sistem Informasi Pelatihan KUM

Sedangkan fungsi-fungsi yang ada dari sudut pandang admin adalah login, logout, mengupdate jadwal, mengikuti forum dan membuat sertifikat. Login dan logout adalah proses dimana admin ingin memulai sesi untuk mengupdate jadwal pelatihan dan menutup sesi. Meng-update jadwal adalah proses dimana admin memperbarui jenis pelatihan dan jadwal pelatihan. Mengikuti forum adalah proses dimana admin mengatur jalannya forum diskusi. Proses membuat sertifikat dapat dilakukan admin melalui sistem karena sistem telah menyediakan formatnya.

Dari hasil identifikasi kebutuhan sistem dengan diagram use case (Gambar 2), kita dapat merancang isi (content), tata letak (layout) serta database dari sistem informasi pelatihan ini. Database yang digunakan memiliki 3 tabel yaitu tabel pendaftaran, tabel jadwal dan tabel admin yang berisi username \& password admin.

Hasil dari perancangan sistem informasi pelatihan KUM berbasis web adalah berupa prototipe yang terdiri dari halaman web yang disediakan bagi pengunjung dan halaman web khusus untuk admin. Pada tulisan ini, prototipe yang dibuat adalah halaman web yang disediakan atau dapat diakses oleh pengunjung, belum mencakup halaman web khusus untuk admin. Halaman web tersebut ditunjukkan pada Gambar 3.

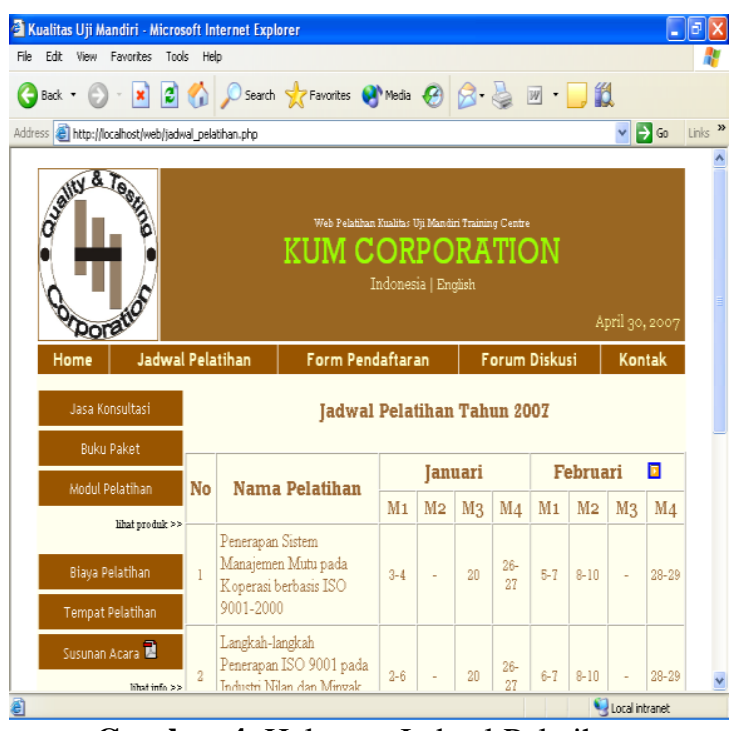

Gambar 4. Halaman Jadwal Pelatihan

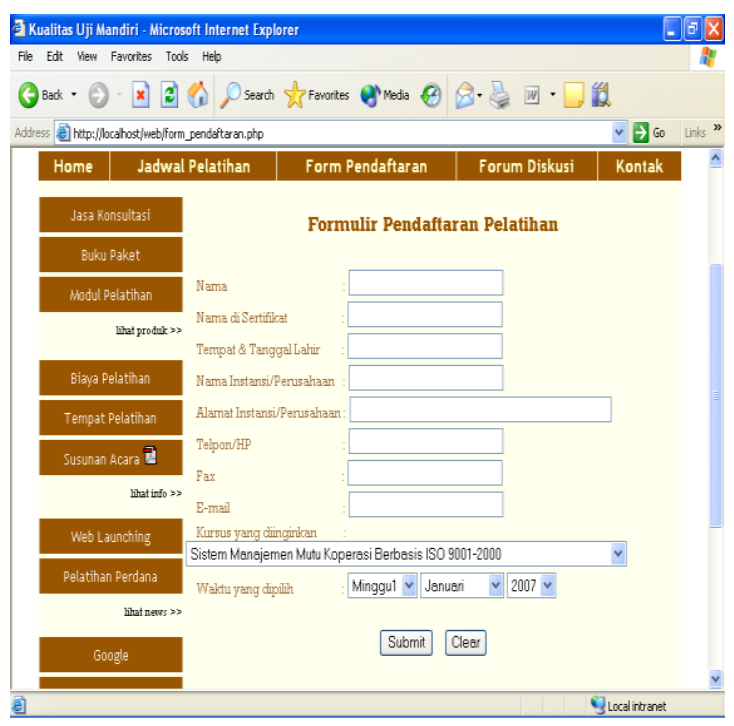

Gambar 5. Halaman Formulir Pendaftaran

Dari Gambar 3 terlihat bahwa halaman web yang dibuat sudah meliputi semua use case yang 
diidentifikasi dari sudut pandang pengunjung (gambar 2) seperti mendaftar (adanya form pendaftaran), browsing info dan mengikuti forum. Info yang dapat diperoleh mencakup berbagai hal seperti jadwal pelatihan, biaya, tempat, berita seputar pelatihan, dan lain-lain. Tampak pula pada Gambar 3 bahwa produk yang ditawarkan tidak hanya jasa pelatihan tetapi juga jasa konsultasi, buku paket dan modul pelatihan.

Dari segi tata letak (layout), fungsi-fungsi seperti jadwal pelatihan, form pendaftaran, forum diskusi terletak pada bagian atas halaman web. Sedangkan informasi mengenai seputar pelatihan dapat diakses di sebelah kiri halaman web. Pembagian layout seperti ini bertujuan memudahkan pengunjung bilamana menelusuri halaman-halaman web (web page) yang ada. Berikut ini adalah isi (content) web yang lainnya yaitu sebagai berikut:

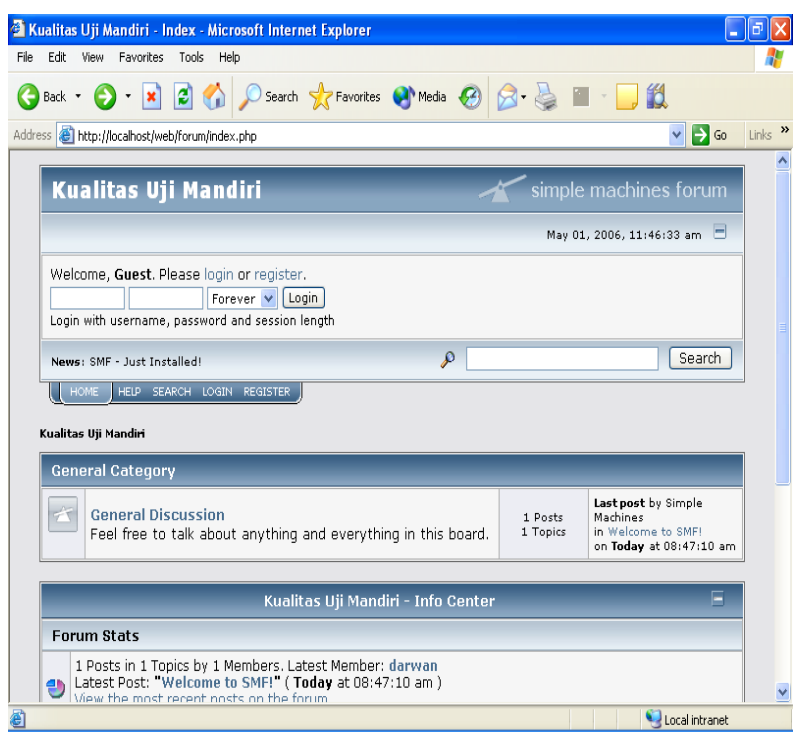

Gambar 6. Halaman Forum Diskusi

Dari Gambar 5 terlihat bahwa data-data peserta pelatihan dapat dimasukkan melalui formulir pendaftaran pelatihan dan data-data tersebut akan disimpan dalam database pendaftaran untuk dapat diambil kembali bila diperlukan. Hal ini memberikan nilai tambah efisiensi karena dapat menghemat penggunaan kertas.

Dari Gambar 6 terlihat bahwa halaman forum diskusi disediakan bagi pengunjung dan admin untuk berdiskusi tentang topik-topik pelatihan yang diikuti. Selain itu pengunjung dapat memberikan saran dan kritik terhadap website serta kualitas pelatihan atau pengajaran yang diperoleh.

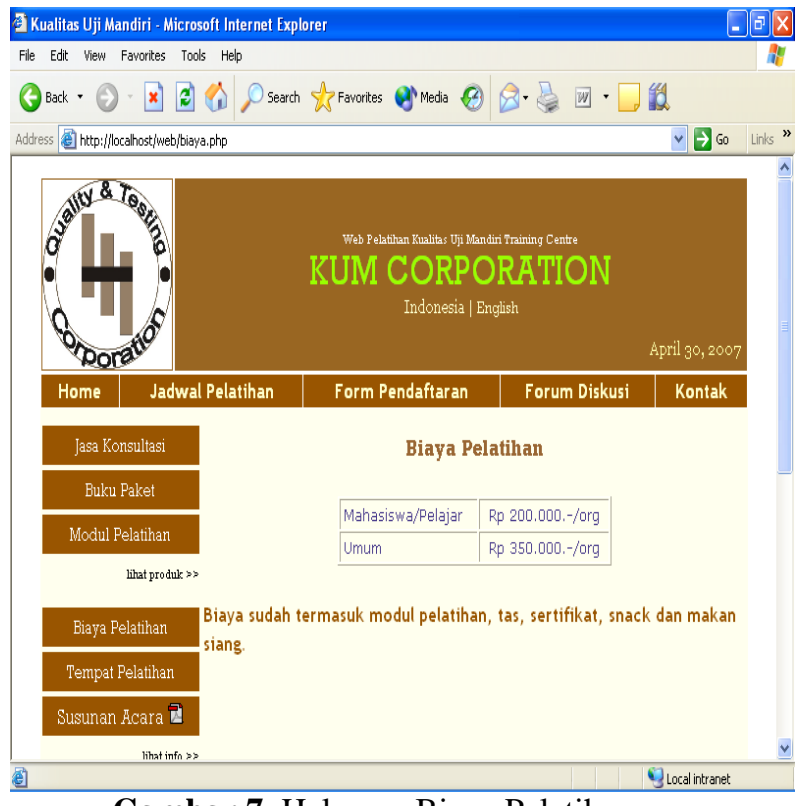

Gambar 7. Halaman Biaya Pelatihan

\section{Kesimpulan}

Berdasarkan hasil penelitian yang telah dilakukan, penulis dapat menarik beberapa kesimpulan:

1. Sistem Informasi Pelatihan Berbasis Web yang dirancang dapat memberikan informasi menyeluruh mengenai jasa pelatihan yang ditawarkan.

2. Sistem Informasi Pelatihan yang dirancang memberikan nilai tambah berupa efisiensi dan efektivitas (kecepatan), sistem terintegrasi dan kemudahan bagi pengunjung untuk memperoleh informasi yang diinginkan.

3. Dengan sistem informasi yang dirancang memungkinkan pendokumentasian tanpa menggunakan kertas (paperless documentation) karena data-data disimpan dalam bentuk elektronik.

\section{REFERENSI}

[1] Dawam Rahardjo, "Apa Kabar Koperasi Indonesia”, Kompas, 2002.

[2] Ira Suwandi, Koperasi, Organisasi Ekonomi Yang Berwatak Sosial, Jakarta: Bharata Karya Aksara, Dedi Blog, 1985.

[3] Turban, Efraim, Jae Lee, David King dan Dennis Viehland, Electronic Commerce : A Managerial Perspective, New Jersey : Prentice Hall, 2004. 